\title{
自動車運転者の視線移動認知計算モデルの検証と改良
}

\author{
正 員 水谷健太郎* \\ 非会員 斎藤 元生 ${ }^{*}$ \\ 非会員 大森 隆司 $*$ * 非会員 伊藤 隆文***
}

\section{Evaluation and Modification of Cognitive Computing Model of Car Driver's Eye Movement}

Kentaro Mizutani*, Member, Genki Saito*, Non-member, Takashi Omori**, Non-member,

Takafumi Itou***, Non-member

\begin{abstract}
In a previous study, we proposed a methodology to estimate a driver's internal cognitive process by his/her eye movement and demonstrated the estimation process by a computer simulation. However, the evaluation of the proposed model in real human driving behavior still remains to be realized. In this study, we analyzed gaze movements of real drivers measured while they were using a driving simulator. The results revealed a partial discrepancy between the eye position distribution generated by the proposed model and the eye position observed in actual human behavior. We discuss on the reason of this discrepancy and improved of our model.
\end{abstract}

キーワード：運転者支援, 運転者モデル, 認知モデル, 視線移動, 運転シミュレータ

Keywords : driver support, driver model, cognitive model, gaze movement, driving simulator

\section{1. 自動車運転者の視線移動モデル}

自動車の運転支援システムにおいて, 運転者と機器間の 緊密な連帯は安全維持の重要な条件である。そのためには, 機器が運転に関する運転者の認知過程の内部状態を推定 し，それに基づいた支援を行うことが有効であろう。そこ で我々は, 運転者の視線移動を予測する認知過程のモデル を構築し, 視線の動きから, 運転者の運転にかかわる内的 な情報処理過程を推定する枠組みを提案してきた ${ }^{(1)}$ 。これ は, 外界のテクスチャー的な視覚特徵から得られる顕著性 (Saliency)に誘発されるボトムアップ視線と，ステアリング 操作に必要な情報取得のためのトップダウン視線の二つの 視線移動要素に基づくモデルである（モデルの詳細は文献 (1)を参照されたい)。トップダウン視線では, 強化学習によ り獲得された予測モデル(2)により, $1,2,3$ 秒後の自車の予測 地点の車線両端に対して視線移動が行われる。これまでは 計算機シミュレーションでモデルの動作検証を行ってきた

* 北海道大学 大学院情報科学研究科

于060-8628 北海道札幌市北区北 14 条西 8 丁目

Graduate School of Information Science and Technology Hokkaido University

Kita14, Nishi8, Kita-ku, Sapporo 060-8628

** 玉川大学 学術研究所

干194-8610 東京都町田市玉川学園 6-1-1

Tamagawa University Research Institute

6-1-1 Tamagawagakuen, Machida-shi, Tokyo 194-8610

*** 株式会社デンソー 基礎研究所

T470-0111 愛知県日進市米野木町南山 500-1

DENSO CORPORATION Research Laboratories

500-1, Minamiyama, Komenoki-cho, Nisshin-shi, Aichi 470-0111
が，本稿では，実際の運転者の視線計測に基づくモデルの 検証と, その結果によるモデルの改良について述べる。

\section{2. 運転シミュレータによる視線計測実験}

運転シミュレータは小型乗用車のカットボディと, その 前方に 3 台のプロジェクタによって車外風景の CG 画像が 投影されるスクリーンからなる。被験者は 4 名（男性 3 名, 女性 1 名）で, 神奈川県横浜市の市街地に基づいて作成さ れた $3.5 \mathrm{Km}$ のコースを往復で走行させた。シミュレーショ ン環境では, 自車以外の自動車や歩行者は存在せず, 被験 者には「道なりに走行するように」とだけ指示し，信号や その他の交通ルールには従わない。走行時の速度は指示し なかったため被験者により異なり, 結果として運転・測定 の所要時間も被験者により異なって約 4 分 30 秒〜 7 分であ った。視線はアイカメラ(nac EMR-7)により被験者の右眼球 の動きを計測した。

視線データは, アイカメラのビデオ映像から 6 フレーム /秒で静止画像列を抽出し, それから視線マーカ位置の物 体を実験者 2 名の合議に基づく目視判定により分類した。 今回は, ステアリング操作のためのトップダウン視線のモ デルを検証するため, 往路コース中の左カーブ区間（道路 縁石の左カーブ頂点が視認できる区間, 往路コース中 5 ケ 所）におけるカーブ頂点, 路面への視線分布を求め, モデ ルシミュレーションによる左カーブ走行のトップダウン視 線と比較した。曲率の異なる複数カーブを共通に比較する ため, 水平方向は道路の左白線と中央線, 垂直方向（道路 
の奥行き方向）は自動車の $1,2,3$ 秒後の予測位置を基準と して正規化し，視線をプロットした（図 1)。

その結果，全ての被験者において視線は左カーブ頂点か ら車線中央付近に分布し, 過去の実車による測定例とも一 致した ${ }^{(3)}$ 。これに対してモデルでは, 左カーブ頂点付近と中 央線付近に視線が分布した。さらに, 垂直方向つまり道路 前方の距離に対する分布を見ると, 1 名の被験者の夕有意に モデルより遠方（上方）への視線分布が確認された。

\section{3. モデルの改良と考察}

従来モデルでは, 車線の中央を走行するために, 車線の 両端（左白線と中央線）を注視し，車両の両側の距離を一 定に保つステアリング操作を行なっていた。実験結果から, これを左右カーブでそれぞれ片方のみを見るモデルに改良 した。つまり, 左カーブでは左白線を見て車両左側の距離

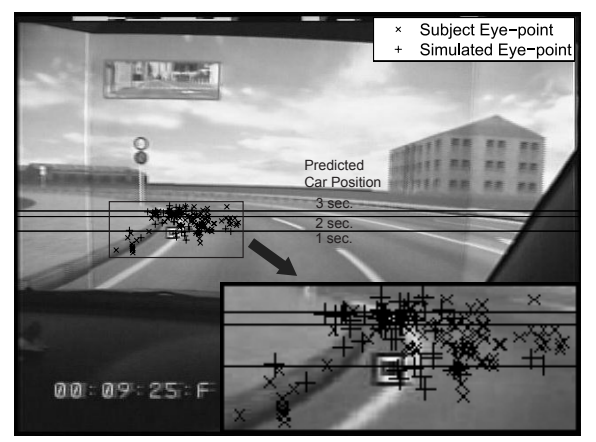

図 1 被験者 1 と改良モデルによる視線分布の例

Fig. 1. Example of eye-point distribution by subject \# 1 and modified model.

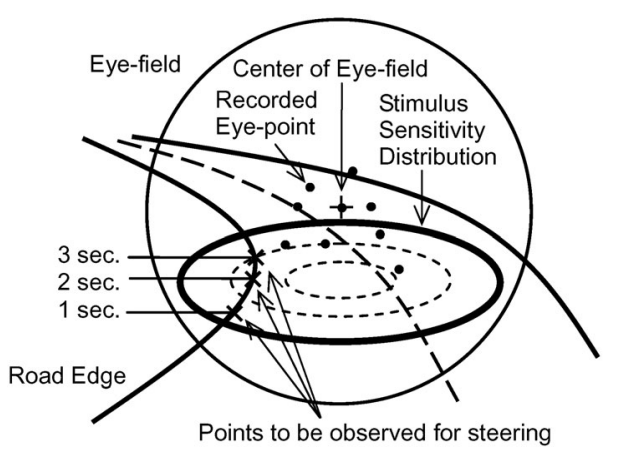

図 2 周辺視野感度分布特性の推定

Fig. 2. Estimation of peripheral eye-sensitivity.

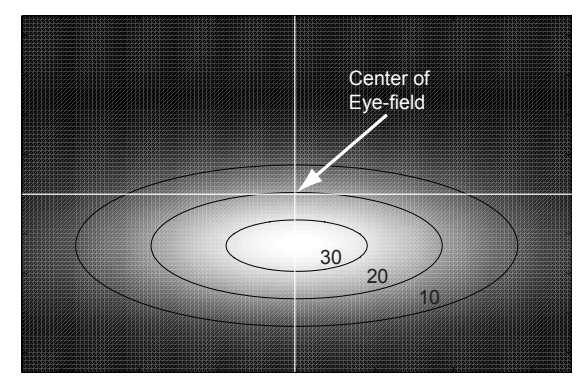

図 3 ステアリング操作のための視野感度分布

Fig. 3. Estimated visual sensitivity distribution for steering operation by a subject.
を一定（1 1.5m）に保ち, 右カーブでは中央線を見て車両 右側の距離を一定に保つ。改良モデルの視線分布を被験者 1 の視線に重ねたものを図 1 に示す。

4 名中 3 名の被験者では, 視線は自車の 1 3 秒後の路面 を中心に分布した。これは, 提案モデルによるトップダウ ン視線と一致し, Land らによる行動実験とも矛盾しない(4)。 一方, 1 名の被験者のみ $2 \sim 6$ 秒後付近のより遠方に視線分 布がみられ，ステアリングのために道路端を注視するモデ ルとは合致しなかった。この理由として我々は，この被験 者が視野の下部でステアリングに必要な路面情報を得てい ると仮定し, 被験者の路面情報の取得に関する「周辺視野 感度分布特性」の推定を試みた。視野中のステアリングに かかわる特徴への感度分布として分布中心が視野の中心か らずれた正規分布(式(1))を仮定した。そして被験者の視線 記録位置を視野中心としたときに, 観測すべき点（1，2，3 秒後の予測位置での道路端部分）の感度が最大となるよう に, $\sigma_{x}, \sigma_{y}, C_{y}$ の 3 パラメータを山登り法により探索した （視野の左右対称性より $C_{X}=0$ とした）（図 2)。その結果を 困 3 に示す。

$$
\operatorname{Eyesens}(x, y)=\frac{1}{2 \pi \sqrt{\sigma_{x} \sigma_{y}}} \exp \left(\frac{-\left(x-C_{x}\right)^{2}}{2 \sigma_{x}^{2}}+\frac{-\left(y-C_{y}\right)^{2}}{2 \sigma_{y}^{2}}\right)
$$

$x, y$ : 視野中心を原点とする座標系, $\sigma_{x}^{2}, \sigma_{y}^{2}$ : 視野 感度分布の分散, $C_{x}, C_{y}$ : 視野感度分布の中心

これは, 視線移動の要因（本稿ではステアリング操作のた めの情報収集）に応じて, 視野内の感度分布が異なる可能 性を示唆する。

以上, 4 名中 3 名の被験者で視線分布が改良モデルと一致 し, 運転シミュレータ上の限定された環境ではあるが, 提 案モデルが運転者のステアリング操作における視線移動の 再現に有効であると考えられる。残る 1 名についても, 本 稿で推定した視野感度分布特性を考慮することでモデルが 適用可能となった。一般に運転時の視線移動は運転への習 熟に伴い減少するといわれる。その習熟と視線移動特性と 視野感度分布の関係については更なる検討が必要である。

(平成 17 年 12 月 19 日受付, 平成 18 年 2 月 16 日再受付)

\section{文献}

(1) K. Mizutani and T. Omori : "A Feasibility Study of Driver's Cognitive Process Estimation from Driving Behavior", IEEJ Trans. EIS, Vol.125, No.6, pp.967-975 (2005-6) (in Japanese) 水谷健太郎・大森隆司: 「運転行動から運転者の認知状態を推定する 計算モデルの検討」, 電学論 C, 125, 6, pp.967-975 (2005-6)

(2) Y. Koike and K. Doya : "A Driver Model Based on Reinforcement Learning with Multi-Step State Estimation", Trans. IEICE Japan D-II, Vol.84-D-II, No.2, pp.370-379 (2001-2) (in Japanese) 小池康晴・銅谷賢治:「マルチステップ状態予測を用いた強化学習に よるドライバモデル」, 信学論 D-II, 84, .2, pp.370-379 (2001-2)

(3) M. F. Land and D. N. Lee : "Where we look when we steer", Nature, Vol.369, pp.742-744 (1994)

(4) M. F. Land and J. Horwood: "Which parts of the road guide steering?", Nature, Vol.377, pp.339-340 (1995) 